\title{
Genetic response to low-intensity ultrasound on mouse ST2 bone marrow stromal cells
}

\author{
YOSHIAKI TABUCHI ${ }^{1,2}$, HIDEYUKI HASEGAWA ${ }^{3}$, NOBUO SUZUKI ${ }^{4}$, YUKIHIRO FURUSAWA $^{5}$, \\ TETSUSHI HIRANO ${ }^{1}$, RYO NAGAOKA ${ }^{3}$, JUN HIRAYAMA ${ }^{6}$, NOBUHIKO HOSHI ${ }^{7}$ and TAKASHI MOCHIZUKI ${ }^{8}$ \\ ${ }^{1}$ Division of Molecular Genetics Research, Life Science Research Center, University of Toyama, \\ Toyama 930-0194; ${ }^{2}$ Graduate School of Innovative Life Science and ${ }^{3}$ Graduate School of Science and Engineering, \\ University of Toyama, Toyama 930-8555; ${ }^{4}$ Noto Marine Laboratory, Institute of Nature and \\ Environmental Technology, Kanazawa University, Ishikawa 927-0553; ${ }^{5}$ Department of Liberal Arts and \\ Sciences, Toyama Prefectural University, Toyama 939-0398; ${ }^{6}$ Department of Clinical Engineering, \\ Faculty of Health Sciences, Komatsu University, Komatsu 923-0961; ${ }^{7}$ Laboratory of Animal Molecular Morphology, \\ Department of Animal Science, Graduate School of Agricultural Science, Kobe University, \\ Kobe 657-8501; ${ }^{8}$ Medical Ultrasound Laboratory, Co., Ltd., Tokyo 250-0014, Japan
}

Received September 13, 2020; Accepted October 27, 2020

DOI: $10.3892 / \mathrm{mmr} .2020 .11812$

Correspondence to: Professor Yoshiaki Tabuchi, Division of Molecular Genetics Research, Life Science Research Center, University of Toyama, 2630 Sugitani, Toyama 930-0194, Japan E-mail: ytabu@cts.u-toyama.ac.jp

Abbreviations: Actb, $\beta$-actin; ALP, alkaline phosphatase; AP-1, activator protein-1; Atf3, activating transcription factor 3; Bag3, BAG cochaperone 3; BMSCs, bone marrow stromal cells; Bglap, bone $\gamma$ carboxyglutamate protein; Cryab, $\alpha \mathrm{B}$-crystallin; Dnaja1, DnaJ heat shock protein family (Hsp40) member A1; Dnaja4, DnaJ heat shock protein family (Hsp40) member A4; Dnajb1, DnaJ heat shock protein family (Hsp40) member B1; Dusp1, dual specificity phosphatase 1; Edn1, endothelin 1; Egr1, early growth response 1; Ehmt2, euchromatic histone lysine N-methyltransferase 2; Etv5, ets variant 5; Fbl, fibrillarin; Fmod, fibromodulin; Fos, FBJ osteosarcoma oncogene; Fosl1, fos-like antigen 1; Gapdh, glyceraldehyde 3-phosphate dehydrogenase; Gja1, gap junction protein, $\alpha$ 1; Glis2, GLIS family zinc finger 2; Gsn, gelsolin; Hsf1, heat shock transcription factor 1 ; Hspa1, heat shock protein $1 \mathrm{a} / \mathrm{b}$; Hspa8, heat shock protein 8; Hspb1, heat shock protein 1; Hsph1, heat shock $105 \mathrm{kDa} / 110 \mathrm{kDa}$ protein 1 ; HSPs, heat shock proteins; IEGs, immediate-early genes; ISATA, spatial-average temporal-average; Itgb1, integrin beta 1; Jun, jun proto-oncogene; Klf10, Kruppel-like factor 10; LIUS, low-intensity ultrasound; Metap2, methionine aminopeptidase 2; PAGE, polyacrylamide gel electrophoresis; Ptgs2, prostaglandin-endoperoxide synthase 2; Ptx3, pentraxin related gene; RT-qPCR, reverse transcription-quantitative polymerase chain reaction; SD, standard deviation; Snai2, snail family zinc finger 2; Srf, serum response factor; Syk, spleen tyrosine kinase; Tff1, trefoil factor 1; Trps1, transcriptional repressor GATA binding 1; Ubc, ubiquitin $\mathrm{C}$

Key words: low-intensity ultrasound, ST2 bone marrow stromal cell, gene expression, immediate-early genes, heat shock proteins
Abstract. Although low-intensity ultrasound (LIUS) is a clinically established procedure, the early cellular effect of LIUS on a genetic level has not yet been studied. The current study investigated the early response genes elicited by LIUS in bone marrow stromal cells (BMSCs) using global-scale microarrays and computational gene expression analysis tools. Mouse ST2 BMSCs were treated with LIUS $\left[I_{\text {SATA }}, 25 \mathrm{~mW} / \mathrm{cm}^{2}\right.$ for 20 min with a frequency of $1.11 \mathrm{MHz}$ in a pulsed-wave mode $(0.2$-s burst sine waves repeated at $1 \mathrm{kHz}$ )], then cultured for $0.5,1$ and $3 \mathrm{~h}$ at $37^{\circ} \mathrm{C}$. The time course of changes in gene expression was evaluated using GeneChip ${ }^{\circledR}$ high-density oligonucleotide microarrays and Ingenuity ${ }^{\circledR}$ Pathway Analysis tools. The results were verified by reverse transcription-quantitative polymerase chain reaction (RT-qPCR). A single exposure of LIUS did not affect cell morphology, cell growth or alkaline phosphatase activity. However, 61 upregulated and 103 downregulated genes were identified from 0.5 to $3 \mathrm{~h}$ after LIUS treatment. Two significant gene networks, labeled $\mathrm{E}$ and $\mathrm{H}$, were identified from the upregulated genes, while a third network, labeled $\mathrm{T}$, was identified from the downregulated genes. Gene network $\mathrm{E}$ or $\mathrm{H}$ containing the immediate-early genes FBJ osteosarcoma oncogene and early growth response 1 or the heat shock proteins heat shock protein $1 a / b$ was associated mainly with the biological functions of bone physiology and protein folding or apoptosis, respectively. Gene network $\mathrm{T}$ containing transcription factors fos-like antigen 1 and serum response factor was also associated with the biological functions of the gene expression. RT-qPCR indicated that the expression of several genes in the gene networks $\mathrm{E}$ and $\mathrm{H}$ were elevated in LIUS-treated cells. LIUS was demonstrated to induce gene expression after short application in mouse ST2 BMSCs. The results of the present study provide a basis for the elucidation of the detailed molecular mechanisms underlying the cellular effects of LIUS. 


\section{Introduction}

Ultrasound technology has many applications for diagnosis and therapy in medicine. Low-intensity ultrasound (LIUS) has also been used to treat fractures. The LIUS protocol for fracture consists of signals of $30 \mathrm{~mW} / \mathrm{cm}^{2}$ spatial average-temporal average $\left(I_{\mathrm{SATA}}\right)$ intensity with a frequency of $1.5 \mathrm{MHz}$ in pulsed-wave mode (0.2-s burst sine waves repeated at $1.0 \mathrm{kHz}$ ) for $20 \mathrm{~min}$ per day $(1,2)$. The ability of LIUS to promote fracture healing has been widely investigated in both experimental vertebrate animal models (3-6) and randomized clinical trials $(7,8)$. Fracture healing is a complex physiological process involving various cell types. A number of in vitro studies have clearly demonstrated LIUS-associated bone-formative responses in cells related to fracture healing (9-21). However, the mechanisms underlying the ability of bone cells to detect and respond to LIUS irradiation remain poorly understood.

To elucidate these mechanisms, we consider that monitoring of the early cellular response to LIUS is crucial. The combination of global-scale DNA microarray analysis and bioinformatics analysis tools has provided a view of the gene expression profiles, biological functions, and gene networks relevant to the LIUS response of cells. Several groups have reported that the gene expression patterns were affected within 3 to $24 \mathrm{~h}$ after LIUS-treatment in several cell types (18-23). However, there has been no report about earlier changes in gene expression profiles shortly after exposure of the cells to LIUS.

Immediate-early genes (IEGs) were reported to be induced within minutes after stimulation and have essential roles in stress responses (24). Previous findings indicated that FBJ osteosarcoma oncogene (Fos), a well-characterized IEG, is induced by mechanical loadings including LIUS (9-13). The Fos protein, a leucine zipper-containing domain, heterodimerizes with the jun proto-oncogene (Jun) protein to form the dimeric transcription factor activator protein-1 (AP-1) (24), which plays an important role in bone formation (25). More recently, we showed that LIUS at an intensity of $25 \mathrm{~mW} / \mathrm{cm}^{2}$ significantly and transiently increased the expression levels of 4 IEGs - Fos, early growth response 1 (Egrl), Jun, and prostaglandin-endoperoxide synthase 2 (Ptgs2) - in mouse ST2 bone marrow stromal cells (BMSCs) (13).

Here, to elucidate the early cellular response to LIUS in cells, the early response genes elicited by LIUS $\left[I_{\mathrm{SATA}}\right.$, $25 \mathrm{~mW} / \mathrm{cm}^{2}$ for $20 \mathrm{~min}$ with a frequency of $1.11 \mathrm{MHz}$ in a pulsed-wave mode $(0.2$-s burst sine waves repeated at $1 \mathrm{kHz})$ ] in mouse ST2 BMSCs were investigated using GeneChip ${ }^{\circledR}$ oligonucleotide microarrays and computational gene expression analysis tools.

\section{Materials and methods}

Cell culture. Mouse ST2 BMSCs (RCB0224) were obtained from the RIKEN BRC through the National Bio-Resource Project of the Ministry of Education, Culture, Sports, Science, and Technology of Japan (MEXT). The cells were maintained in RPMI-1640 medium (Nacalai Tesque, Inc.) supplemented with $10 \%$ fetal bovine serum (Equitech-Bio, Inc.) at $37^{\circ} \mathrm{C}$ in humidified atmosphere of $95 \%$ air with $5 \% \mathrm{CO}_{2}$. For the LIUS

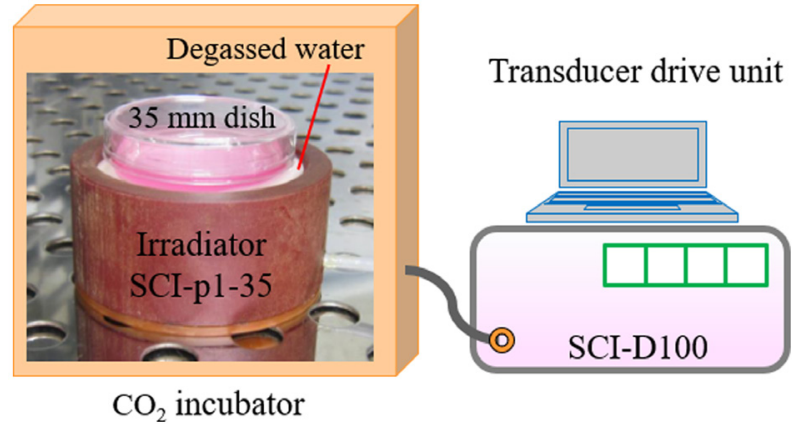

Figure 1. Set-up for low-intensity ultrasound exposure.

experiments, the cells $\left(2 \times 10^{5}\right.$ cells $)$ were seeded on a $35-\mathrm{mm}$ plastic culture dish (Nippon Genetics Co., Ltd.) with $2 \mathrm{ml}$ of culture medium and cultured at $37^{\circ} \mathrm{C}$ for $24 \mathrm{~h}$.

LIUS treatment. LIUS treatment was applied by an ultrasound irradiating system, which consists of an irradiator SCI-p1-35 (Medical Ultrasound Co., Ltd.) with a ceramic transducer (28 $\mathrm{mm}$ diameter, $2 \mathrm{~mm}$ thickness) and SCI-D100 driving equipment (Nepa Gene Co., Ltd.). The LIUS signal had a $I_{\text {SATA }}$ of $25 \mathrm{~mW} / \mathrm{cm}^{2}$, with a frequency of $1.11 \mathrm{MHz}$ in a pulsed-wave mode (0.2-s burst sine waves repeated at $1 \mathrm{kHz})(13)$. LIUS was transmitted through the bottom of the culture dish in a $\mathrm{CO}_{2}$ incubator at $37^{\circ} \mathrm{C}$ (Fig. 1). The cells were irradiated with LIUS for $20 \mathrm{~min}$, followed by incubation for $0,0.5,1,3$ or $24 \mathrm{~h}$ at $37^{\circ} \mathrm{C}$. For heat treatment, cells were exposed to $38,39,40,41$ and $42^{\circ} \mathrm{C}$ for $20 \mathrm{~min}$ in a water bath. After heat treatment, the cells were incubated for 0 or $0.5 \mathrm{~h}$ at $37^{\circ} \mathrm{C}$. The temperature of the culture medium was monitored with a digital thermometer (SK-1110, Sato Keiryoki MFG Co., Ltd.) coupled to a type K thermocouple sensor (SK-K020, Sato Keiryoki MFG Co., Ltd.) (13).

Morphological and cell growth analyses. Cell morphology was observed using a phase-contrast microscopy. For cell growth, Cell Count Reagent SF (Nacalai Tesque Inc.), a water-soluble tetrazolium salt WST-8 based assay, was used. Cells were incubated with WST- 8 solution at $37^{\circ} \mathrm{C}$. Thirty min later, the produced formazan dye concentration was determined from the absorbance at $450 \mathrm{~nm}(26)$.

Assay of alkaline phosphatase (ALP) activity. Cellular material was placed into $50 \mathrm{mM}$ Tris- $\mathrm{HCl}$ buffer $(\mathrm{pH} 7.2)$ containing $0.01 \%$ Triton $\mathrm{X}-100$ and homogenized by an ultrasonic disruptor (UD-200, Tomy Co.). ALP activity of the cell homogenate was measured by using a protocol supplied by Sigma (Sigma-Aldrich; Merck KGaA). The absorbance at $405 \mathrm{~nm}$ was read on a plate reader (13). The protein concentration was determined with a bicinchoninic acid assay.

RNA isolation. Total RNA was isolated from cells using a NucleoSpin ${ }^{\circledR}$ RNA Plus isolation kit (MACHEREY-NAGEL GmbH \& Co.) and treated with NucleoSpin ${ }^{\circledR}$ genomic DNA removal column (MACHEREY-NAGEL GmbH \& Co.) to remove residual genomic DNA. The concentration of RNA was measured by spectroscopy with an expected A260/A280 ratio close to 2. Qualitative assessment of the 
Table I. Nucleotide sequences of the primer pairs and a probe for target genes.

\begin{tabular}{|c|c|c|c|}
\hline Gene & Orientation & Nucleotide sequence (position) & GenBank accession no. \\
\hline \multirow[t]{2}{*}{$A c t b$} & Sense & ACCCTAAGGCCAACCGTGAA (441-460) & NM_007393 \\
\hline & Antisense & TGTGGTACGACCAGAGGCATAC (556-535) & \\
\hline \multirow[t]{2}{*}{ Bag3 } & Sense & CCAAATCGGGAGAAGCCGAAAC (1514-1535) & NM_013863 \\
\hline & Antisense & TCGTCCTTCAGGGTCTACGGAA (1710-1689) & \\
\hline \multirow[t]{3}{*}{ Bglap } & Sense & GGCAATAAGGTAGTGAAC (169-187) & NM_007541 \\
\hline & Antisense & GCCATACTGGTCTGATAG (297-279) & \\
\hline & Probe & FAM-CGCTACCTTGGAGCCTCAGT-TAMRA (196-216) & \\
\hline \multirow[t]{2}{*}{ Dnajbl } & Sense & AGATCTACAGCGGCTGTACC (678-697) & NM_018808 \\
\hline & Antisense & AGCCCCTCTTCACTTCGATG (791-772) & \\
\hline \multirow[t]{2}{*}{ Egrl } & Sense & ATGAGCACCTGACCACAGAG (563-582) & NM_007913 \\
\hline & Antisense & GAGGCAGAGGAAGACGATGA (830-811) & \\
\hline \multirow[t]{2}{*}{ Fos } & Sense & TGCAAGATCCCCGATGACCT (749-768) & NM_010234 \\
\hline & Antisense & TCAGCTCCACGTTGCTGATG (932-913) & \\
\hline \multirow[t]{2}{*}{ Hspala } & Sense & GAACGCGCTCGAATCCTATG (1848-1867) & NM_010479 \\
\hline & Antisense & GAGATGACCTCCTGGCACTT (1917-1899) & \\
\hline \multirow[t]{2}{*}{ Hspbl } & Sense & CTGGCAAGCACGAAGAAAGG (514-533) & NM_013560 \\
\hline & Antisense & AGGGGATAGGGAAGAGGACA (629-610) & \\
\hline \multirow[t]{2}{*}{$\operatorname{Ptgs} 2$} & Sense & TTCTCCCTGAAGCCGTACAC (1559-1578) & NM_011198 \\
\hline & Antisense & GGCAGGGTACAGTTCCATGA (1669-1650) & \\
\hline
\end{tabular}

Actb, $\beta$-actin; Bag3, BCL2-associated athanogene 3; Bglap, bone $\gamma$ carboxyglutamate protein; Dnajb1, DnaJ heat shock protein family (Hsp40) member B1; Egrl, early growth response 1; Fos, FBJ osteosarcoma oncogene; Hspala, heat shock protein 1A; Hspb1, heat shock protein 1; Ptgs2, prostaglandin-endoperoxide synthase 2.

RNA was also checked using a Bioanalyzer 2100 (Agilent Technologies, Inc.). RNA samples (RNA integrity number values: >9.5) were used (26).

Microarray gene expression and gene network analyses. Microarray analysis was performed using a GeneChip ${ }^{\circledR}$ system with a Mouse Genome 4302.0 array (Affymetrix, Inc.) spotted with 45,101 probe sets. Array samples were prepared as described in the Affymetrix GeneChip ${ }^{\circledR}$ Expression Technical Manual. Total RNA from three experiments was pooled, and $500 \mathrm{ng}$ of the RNA was used to synthesize cRNA with a GeneChip ${ }^{\circledR} 3^{\prime}$ IVT Express Kit (Affymetrix, Inc.). The array was hybridized with biotin-labeled cRNA at $45^{\circ} \mathrm{C}$ for $16 \mathrm{~h}$. After the treatment with phycoerythrin-labeled streptavidin, the array was scanned using a prove array scanner (Affymetrix GeneChip $^{\circledR}$ Scanner 3000). The obtained hybridization intensity data were further analyzed using GeneSpring ${ }^{\circledR}$ GX (Agilent Technologies, Inc.) to extract the significant genes and Ingenuity ${ }^{\circledR}$ Pathway Analysis tools (Tomy Digital Biology, Co., Ltd.) to examine gene ontology, including biological processes, cellular components, molecular functions, and gene networks $(21,27)$.

Real-time quantitative polymerase chain reaction ( $q R T-P C R$ ) assay. qRT-PCR was carried out on an Mx3005P real-time PCR system (Agilent Technologies, Inc.) as described previously (13). The specific primer and probe sequences are listed in Table I. $\beta$-actin (Actb) was used as an internal control.
Separation of total cellular, cytoplasmic and nuclear fractions. For separation of total cellular fraction, cells were lysed with lysis buffer $(50 \mathrm{mM} \mathrm{NaCl}, 1 \%$ Nonidet P-40 and $50 \mathrm{mM}$ Tris- $\mathrm{HCl}, \mathrm{pH}$ 8.0) containing protease inhibitor cocktail (Nacalai Tesque, Inc.). For separation of cytoplasmic and nuclear fractions, cells were lysed in the fractionation buffer [phosphate-buffered saline containing 0.1\% Nonidet P-40 and the protease inhibitor cocktail (Nacalai Tesque, Inc.)] and centrifuged at $15,000 \mathrm{x}$ g for $10 \mathrm{sec}$ at $4^{\circ} \mathrm{C}$ to obtain the cytosolic fraction (supernatants). The insoluble pellets were resuspended in the fractionation buffer and centrifuged at $15,000 \mathrm{x} \mathrm{g}$ for $10 \mathrm{sec}$ at $4^{\circ} \mathrm{C}$ to obtain the nuclear fraction (pellets). Either glyceraldehyde 3-phosphate dehydrogenase (Gapdh) or fibrillarin (Fbl) was used as the cytoplasmic or nuclear marker protein, respectively (26).

SDS-polyacrylamide gel electrophoresis (PAGE) and Western blotting. SDS-PAGE and Western blotting were carried out according to our previous reports (26). Proteins were detected using the following primary antibodies: rabbit polyclonal anti-heat shock transcription factor 1 (Hsf1) antibody (1:2,000 dilution, cat. no. 4356; Cell Signaling Technology, Inc.), mouse monoclonal anti-Gapdh antibody (1:2,000 dilution, cat. no. 60004-1-Ig; Proteintech Group, Inc.) and rabbit monoclonal anti-Fbl antibody (1:2,000 dilution, cat. no. 2639; Cell Signaling Technology, Inc.). Secondary fluorescent IRDye-conjugated anti-rabbit and anti-mouse antibodies (1:10,000 dilution, LI-COR Biosciences) were also used. 


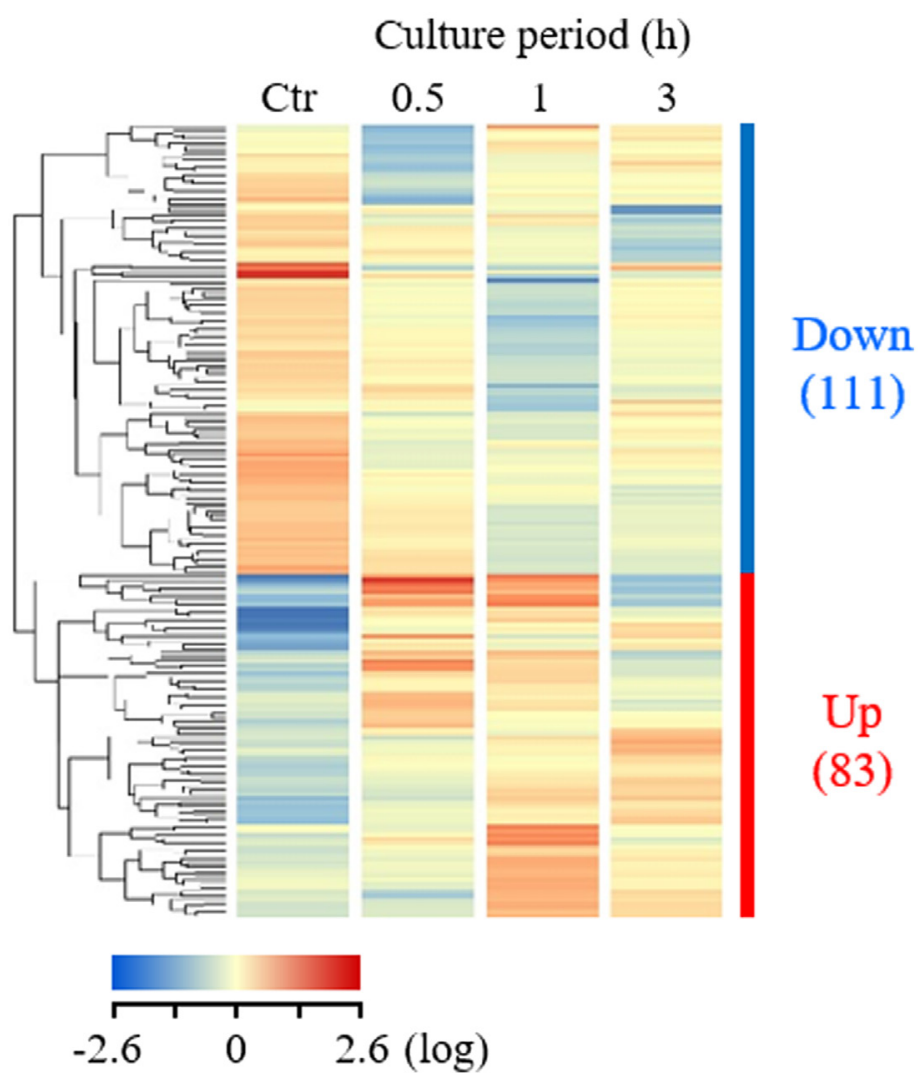

Figure 2. Hierarchical clustering of 194 probe sets differentially expressed by $>2.0$ in the cells exposed to LIUS. After treatment with LIUS at $25 \mathrm{~mW} / \mathrm{cm}^{2}$ for $20 \mathrm{~min}$, the cells were cultured for $0.5,1$ and $3 \mathrm{~h}$ at $37^{\circ} \mathrm{C}$. Clustering was carried using GeneSpring ${ }^{\circledR} \mathrm{GX}$ software. Non-treated cells served as the control. The number in parentheses indicates the number of probe sets. LIUS, low-intensity ultrasound; Ctr, control; Down, downregulated; Up, upregulated.

Fluorescence images were acquired using an Odyssey Infrared Imager (LI-COR Biosciences), and the band density was quantified using Image Studio 5.1 software (LI-COR Biosciences).

Statistical analysis. Statistical analysis was performed using KaleidaGraph version 4.1 software (Hulinks, Inc.). Data were expressed as the means \pm standard deviation (SD) of $\geq 3$ repeated experiments. Differences between groups were analyzed by ANOVA, and correction for multiple comparisons was made using Tukey's post hoc test. Comparisons between two groups were made by using Student's t-test. Statistically significance was set at P-values $<0.05$.

\section{Results}

Effects of LIUS on the morphology, growth and ALP activity of ST2 BMSCs. ST2 BMSCs were exposed to a single LIUS irradiation $\left(25 \mathrm{~mW} / \mathrm{cm}^{2}\right.$ for $20 \mathrm{~min}$ ) followed by culturing at $37^{\circ} \mathrm{C}$ for $24 \mathrm{~h}$. Microscopic investigations demonstrated that ST2 BMSCs had a fibroblast-like morphology. LIUS treatment did not change the ST2 morphology (Fig. S1). Moreover, LIUS treatment did not affect cell growth or ALP activity, a marker for osteoblast differentiation (Fig. S2), as it did in our previous investigations (13).

Gene expression analysis. After a single LIUS treatment, the cells were cultured at $37^{\circ} \mathrm{C}$ for $0.5,1$, and $3 \mathrm{~h}$. Global-scale gene expression analysis was carried out using a GeneChip ${ }^{\circledR}$ Mouse Genome 4302.0 oligonucleotide array. Of the 45,101 probe sets analyzed, approximately 20,000 probe sets were significantly expressed in either control or LIUS-treated cells. The complete lists of genes from the ST2 cell samples have been deposited in the Gene Expression Omnibus, a public database (accession number: GSE135935). GeneSpring ${ }^{\circledR}$ software-based expression analysis of cells exposed to LIUS demonstrated many probe sets that were differentially regulated by a factor of 2.0 or greater. As shown in a hierarchical clustering heatmap (Fig. 2), 83 and 111 probe sets were found to be upregulated and downregulated, respectively, in ST2 cells $0.5,1$ and $3 \mathrm{~h}$ after LIUS treatment.

Biological function and gene network analyses. Next, biological function and gene network analyses were conducted by using the Ingenuity ${ }^{\circledR}$ Pathways Knowledge Base. A total of 61 upregulated and 103 downregulated, functionally annotated genes were identified in the 83 and 111 differentially expressed probe sets, respectively. The top 10 upregulated and top 10 downregulated genes are shown in Tables II and III, respectively. Moreover, 2 significant gene networks, labeled $\mathrm{E}$ (early-response) and $\mathrm{H}$ (Hsf1-regulated), were identified from the upregulated genes (Figs. 3 and 4), while a third network, labeled $\mathrm{T}$ (transcription-related), was identified from the downregulated genes (Fig. 5). Gene network E included 11 genes - 3 IEGs (Fos, Egrl and Ptgs2) plus activating transcription factor 3 (Atf3), bone $\gamma$ carboxyglutamate protein (Bglap), dual specificity phosphatase 1 (Duspl), endothelin1 $(E d n 1)$, fibromodulin (Fmod), gap junction protein, $\alpha 1$ (Gjal), Kruppel-like factor 10 (KlflO) and transcriptional 
Table II. Top 10 upregulated genes.

\begin{tabular}{|c|c|c|c|c|}
\hline \multirow[b]{2}{*}{ Gene symbol } & \multicolumn{3}{|c|}{ Fold-change } & \multirow[b]{2}{*}{ Description } \\
\hline & $0.5 \mathrm{~h}$ & $1 \mathrm{~h}$ & $3 \mathrm{~h}$ & \\
\hline Hspala & 73.0 & 102.6 & 14.5 & Heat shock protein $1 \mathrm{~A}$ \\
\hline Fos & 26.8 & 11.0 & 1.9 & FBJ osteosarcoma oncogene \\
\hline Hspalb & 10.5 & 11.0 & 7.3 & Heat shock protein $1 \mathrm{~B}$ \\
\hline Egrl & 10.0 & 5.6 & 1.5 & Early growth response 1 \\
\hline Hspbl & 6.2 & 6.3 & 9.1 & Heat shock protein 1 \\
\hline St3gal6 & 5.8 & 1.8 & 3.5 & ST3 beta-galactoside $\alpha$-2,3-sialyltransferase 6 \\
\hline Dnajbl & 5.4 & 6.4 & 1.2 & DnaJ (Hsp40) homolog, subfamily B, member 1 \\
\hline $\operatorname{Arc}$ & 5.3 & 4.0 & 0.9 & Activity regulated cytoskeletal-associated protein \\
\hline Dnaja4 & 5.3 & 7.9 & 5.4 & DnaJ (Hsp40) homolog, subfamily A, member 4 \\
\hline Hspa8 & 5.1 & 2.6 & 0.7 & Heat shock protein 8 \\
\hline
\end{tabular}

Table III. Top 10 downregulated genes.

\begin{tabular}{|c|c|c|c|c|}
\hline \multirow[b]{2}{*}{ Gene symbol } & \multicolumn{3}{|c|}{ Fold-change } & \multirow[b]{2}{*}{ Description } \\
\hline & $0.5 \mathrm{~h}$ & $1 \mathrm{~h}$ & $3 \mathrm{~h}$ & \\
\hline Ddahl & 0.10 & 0.04 & 0.06 & Dimethylarginine dimethylaminohydrolase 1 \\
\hline Gsn & 0.13 & 0.15 & 0.11 & Gelsolin \\
\hline$F \operatorname{lnc}$ & 0.18 & 0.18 & 0.60 & Filamin $\mathrm{C}, \gamma$ \\
\hline Itgbl & 0.19 & 0.18 & 0.30 & Integrin beta 1 \\
\hline$D d x 55$ & 0.20 & 0.52 & 0.61 & DEAD (Asp-Glu-Ala-Asp) box polypeptide 55 \\
\hline Riok1 & 0.30 & 0.77 & 0.88 & RIO kinase 1 \\
\hline Pcsk4 & 0.31 & 0.79 & 0.62 & Proprotein convertase subtilisin/kexin type 4 \\
\hline Cerk & 0.36 & 0.66 & 0.67 & Ceramide kinase \\
\hline Tbca & 0.36 & 0.64 & 0.84 & Tubulin cofactor A \\
\hline Nlgn2 & 0.37 & 0.38 & 0.50 & Neuroligin 2 \\
\hline
\end{tabular}

repressor GATA binding 1 (Trps1) - and was associated with the biological functions of differentiation of bone cells, remodeling of bone, and ossification of bone (Fig. 3, Table IV). Gene network $\mathrm{H}$ included 10 genes - 7 heat shock proteins (HSPs) [DnaJ heat shock protein family (Hsp40) member A1 (Dnajal), DnaJ heat shock protein family (Hsp40) member A4 (Dnaja4), DnaJ heat shock protein family (Hsp40) member B1 (Dnajb1), heat shock protein 1a/b (Hspal), heat shock protein 8 (Hspa8), heat shock protein 1 (Hspbl) and heat shock $105 \mathrm{kDa} / 110 \mathrm{kDa}$ protein 1 (Hsph1)] plus BAG cochaperone 3 (Bag3), $\alpha \mathrm{B}$-crystallin $(\mathrm{Cry} a b)$ and ubiquitin $\mathrm{C}$ $(U b c)$ - and was associated with the biological functions of protein folding, protein refolding, and apoptosis (Fig. 4, Table IV). Ingenuity ${ }^{\circledR}$ pathway analysis also indicated that the Hsf1 protein was predicted to be activated at 0.5 to $3 \mathrm{~h}$ after LIUS stimulation (Fig. 4). In addition, we identified 9 genes in gene network T - 6 transcription factors [euchromatic histone lysine N-methyltransferase 2 (Ehmt2), ets variant 5 (Etv5), fos-like antigen 1 (Fosll), GLIS family zinc finger 2 (Glis2), snail family zinc finger 2 (Snai2) and serum response factor
$(S r f)]$ plus gelsolin $(G s n)$, spleen tyrosine kinase $(S y k)$ and trefoil factor 1 (Tff1). This network was associated with the biological functions of transcription, expression of RNA and activation of DNA endogenous promoter (Fig. 5, Table IV).

Verification of upregulated genes by $q R T-P C R$ assay. Eight upregulated genes were chosen: Bglap, Egrl, Fos, and Ptgs2 from gene network E, and Bag3, Dnajbl, Hspal and Hspbl from gene network $\mathrm{H}$. As shown in Fig. 6, treatment of cells with LIUS at $25 \mathrm{~mW} / \mathrm{cm}^{2}$ for 20 min significantly elevated the expression levels of all 8 genes. The expression levels peaked at 0.5-1.0 h after LIUS stimulation in 7 genes, i.e., Egrl, Fos, Ptgs2, Bag3, Dnajb1, Hspal and Hspb1. On the other hand, the peak expression level of Bglap was observed $3 \mathrm{~h}$ after LIUS exposure (Fig. 6).

Effects of LIUS on the Hsfl activation. Under heat-stress conditions, the induction of HSPs principally occurs through the activation of Hsfl. It is well known that the mobility shift and nuclear translocation of Hsf1 due to its phosphorylation 


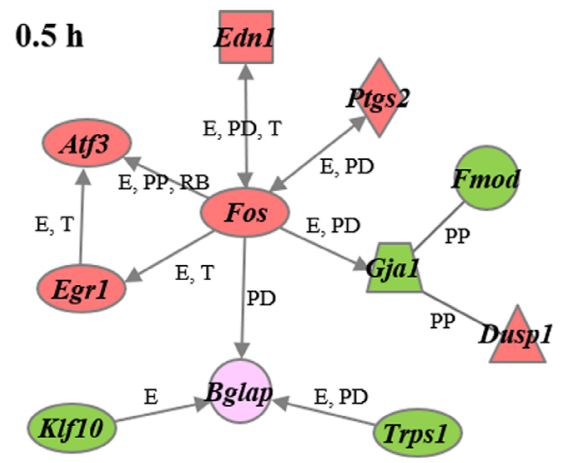

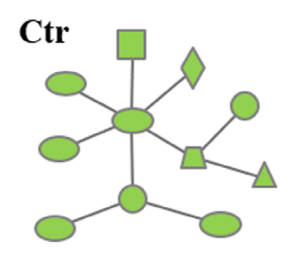

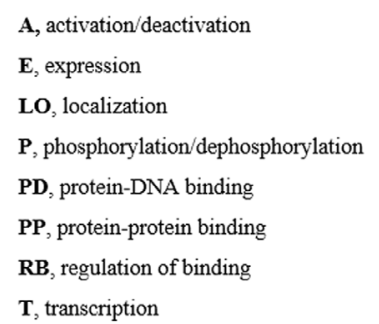

$1 \mathrm{~h}$

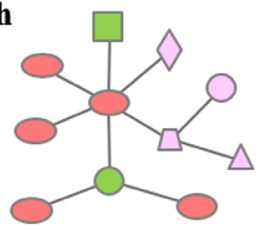

$3 \mathrm{~h}$

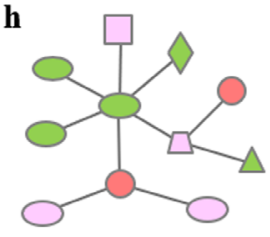

A B binding only

A $\longrightarrow$ B acts on

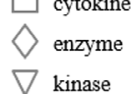

others

$\triangle$ phosphatase

$\square$ transporter

$\bigcirc$ transcription regulator
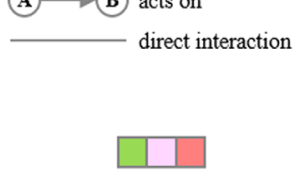

$<0 \quad 0.5(\log )$

Figure 3. Early-response gene network. Upregulated genes were analyzed using Ingenuity ${ }^{\circledR}$ Pathway Analysis tools. The network is presented graphically as nodes (genes) and edges (the biological relationships between the nodes). Atf3, activating transcription factor 3; Bglap, bone $\gamma$ carboxyglutamate protein; Dusp1, dual specificity phosphatase 1; Egrl, early growth response 1; Ednl, endothelin 1; Fmod, fibromodulin; Fos, FBJ osteosarcoma oncogene; Gjal, gap junction protein, $\alpha$ 1; Klf10, Kruppel-like factor 10; Ptgs2, prostaglandin-endoperoxide synthase 2; Trps1, transcriptional repressor GATA binding 1.

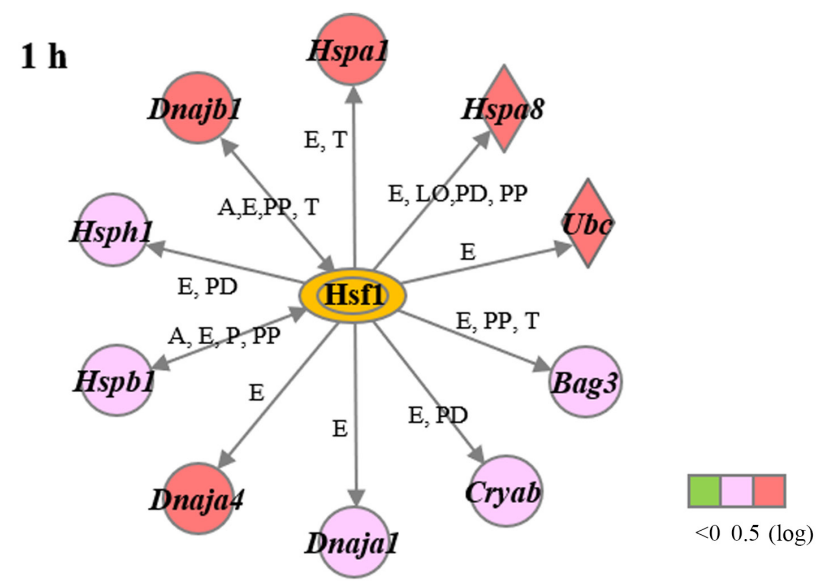

Ctr

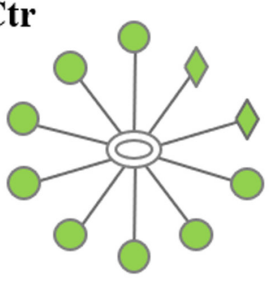

$0.5 \mathrm{~h}$

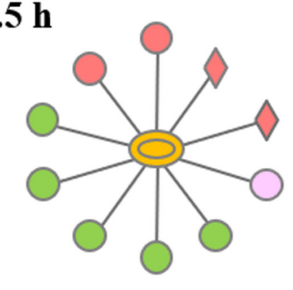

3 h

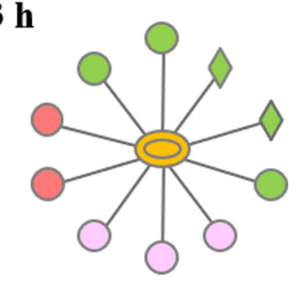

Protein status

Hsfl protein

Activated

Figure 4. Hsf1-regulated gene network. Upregulated genes were analyzed using Ingenuity ${ }^{\circledR}$ Pathway Analysis tools. The network is presented graphically as nodes (genes) and edges (the biological relationships between the nodes). A, activation; E, expression; LO, localization; P, phosphorylation/dephosphorylation; PD, protein-DNA binding; PP, protein-protein binding; T, transcription. Bag3, BAG cochaperone 3; Cryab, $\alpha \mathrm{B}$-crystallin; Dnaja1, DnaJ heat shock protein family (Hsp40) member A1; Dnaja4, DnaJ heat shock protein family (Hsp40) member A4; Dnajb1, DnaJ heat shock protein family (Hsp40) member B1; Hsf1, heat shock transcription factor $1 ;$ Hspal, heat shock protein 1a/b; Hspa8, heat shock protein 8 ; Hspbl, heat shock protein $1 ;$ Hsph1, heat shock 105kDa/110kDa protein $1 ; U b c$, ubiquitin $\mathrm{C}$. 
Table IV. Biological functions in gene networks.

\begin{tabular}{|c|c|c|}
\hline Name & P-value & Genes \\
\hline \multicolumn{3}{|l|}{ Gene network E } \\
\hline Differentiation of bone cells & $2.83 \times 10^{-8}$ & Bglap, Edn1, Fos, Gja1, Klf10 and Ptgs2 \\
\hline Remodeling of bone & $5.19 \times 10^{-10}$ & Bglap, Edn1, Egr1, Fos, Gjal and Ptgs2 \\
\hline Ossification of bone & $2.39 \times 10^{-9}$ & Fmod, Gjal, Klf10, Ptgs2 and Trps1 \\
\hline \multicolumn{3}{|l|}{ Gene network $\mathrm{H}$} \\
\hline Folding of protein & $6.37 \times 10^{-13}$ & Cryab, Dnajal, Dnaja4, Hspa8, Hspal and Hspbl \\
\hline Refolding of protein & $3.56 \times 10^{-11}$ & Dnajal, Dnaja4, Hspa8 and Hspal \\
\hline Apoptosis & $2.00 \times 10^{-6}$ & Bag3, Cryab, Dnajal, Dnajb1, Hspa8, Hspal, Hspb1, Hsph1 and Ube \\
\hline \multicolumn{3}{|l|}{ Gene network T } \\
\hline Transcription & $1.84 \times 10^{-9}$ & Ehmt2, Etv5, Fosl1, Glis2, Gsn, Snai2, Srf, Syk and Tff1 \\
\hline Expression of RNA & $3.70 \times 10^{-9}$ & Ehmt2, Etv5, Fosl1, Glis2, Gsn, Snai2, Srf, Syk and Tff1 \\
\hline Activation of DNA endogenous promoter & $1.76 \times 10^{-6}$ & Ehmt2, Etv5, Fosl1, Glis2, Snai2a and Srf \\
\hline
\end{tabular}

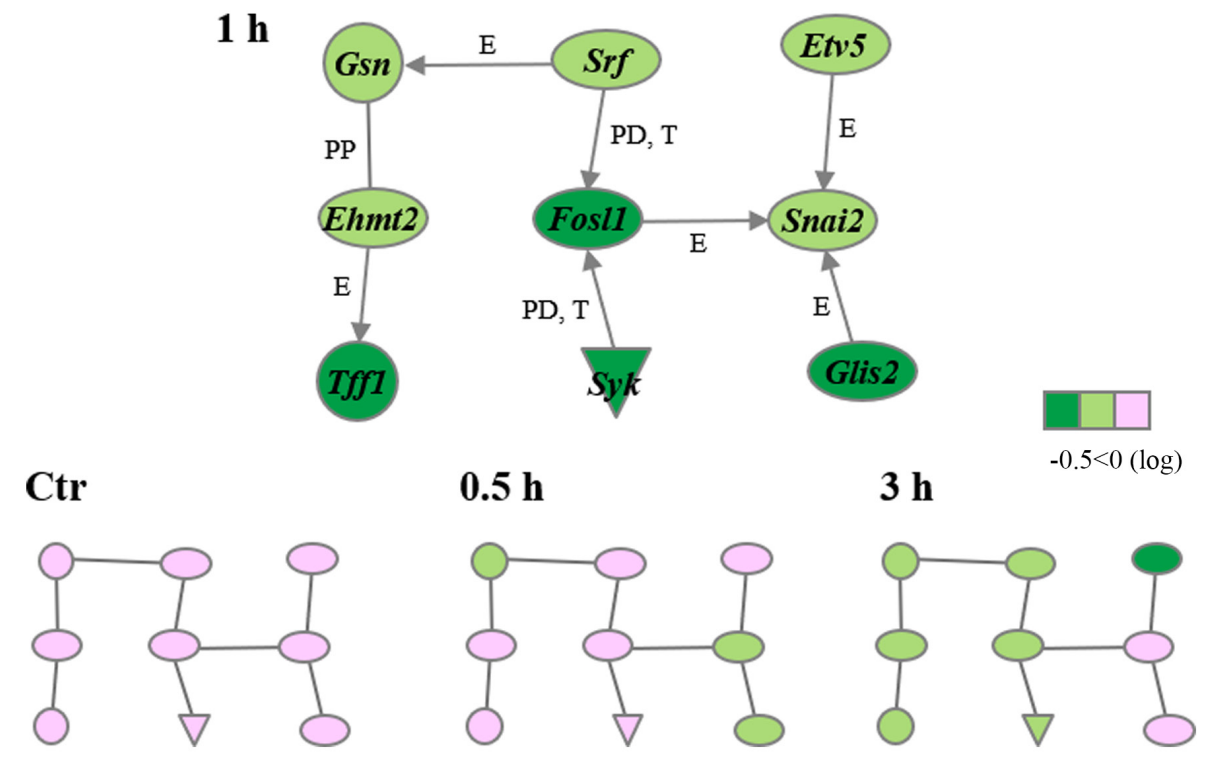

Figure 5. Transcription-related gene network. Downregulated genes were analyzed using Ingenuity ${ }^{\circledR}$ Pathway Analysis tools. The network is presented graphically as nodes (genes) and edges (the biological relationships between the nodes). E, expression; PP, protein-protein binding; PD, protein-DNA binding; T, transcription. Ehmt2, euchromatic histone lysine N-methyltransferase 2; Etv5, ets variant 5; Fosll, fos-like antigen 1; Glis2, GLIS family zinc finger 2; Gsn, gelsolin; Snai2, snail family zinc finger 2; Srf, serum response factor; Syk, spleen tyrosine kinase; Tffl, trefoil factor 1.

indicates activation of the molecule (28). Here, LIUS $\left(25 \mathrm{~mW} / \mathrm{cm}^{2}\right.$ for $20 \mathrm{~min}$ ) induced the temperature rise of the culture medium from $35.3 \pm 0.23^{\circ} \mathrm{C}$ (control) to $38.1 \pm 0.29^{\circ} \mathrm{C}$ (mean $\pm \mathrm{SD}, \mathrm{n}=4$ ). Under control conditions, the ratio of phosphorylated Hsf1 (mobility shift of Hsf1) to non-phosphorylated Hsf1 was very low. On the other hand, a slight but significant mobility shift of Hsf1 was observed at $0 \mathrm{~h}$ after the LIUS treatment (Fig. 7A and C). Under heat-treated conditions, the mobility shift of Hsf1 $0 \mathrm{~h}$ after the heat exposure was markedly and significantly increased in a temperature-dependent manner (Fig. 7B and D). As shown in Fig. 8, Hsf1 was principally localized in the cytosolic compartments in the control cells. Treatment of cells with LIUS significantly induced the nuclear localization of Hsf1 (Fig. 8A and C). This translocation was comparable to that in the cells treated with heat at $40^{\circ} \mathrm{C}$ for
$20 \mathrm{~min}$. On the other hand, the ratio of nucleus Hsf1 to cytoplasm Hsf1 was dramatically elevated in the cells treated with heat at $42^{\circ} \mathrm{C}$ for $20 \mathrm{~min}$ (Fig. 8A and D). These data suggested that Hsf1 is activated in the cells treated with LIUS.

\section{Discussion}

LIUS has clear clinical potential for bone fracture healing. However, the molecular mechanisms underlying the ability of bone cells to detect LIUS stimulation have not been well understood. Here, when we used our developed irradiating system (13) to apply a single LIUS irradiation at an $I_{\text {SATA }}$ of $25 \mathrm{~mW} / \mathrm{cm}^{2}$ for $20 \mathrm{~min}$, which is approximately equivalent to the clinical condition $\left(30 \mathrm{~mW} / \mathrm{cm}^{2}\right.$ for $\left.20 \mathrm{~min}\right)(1,2)$, we identified many differentially expressed genes and 3 unique 

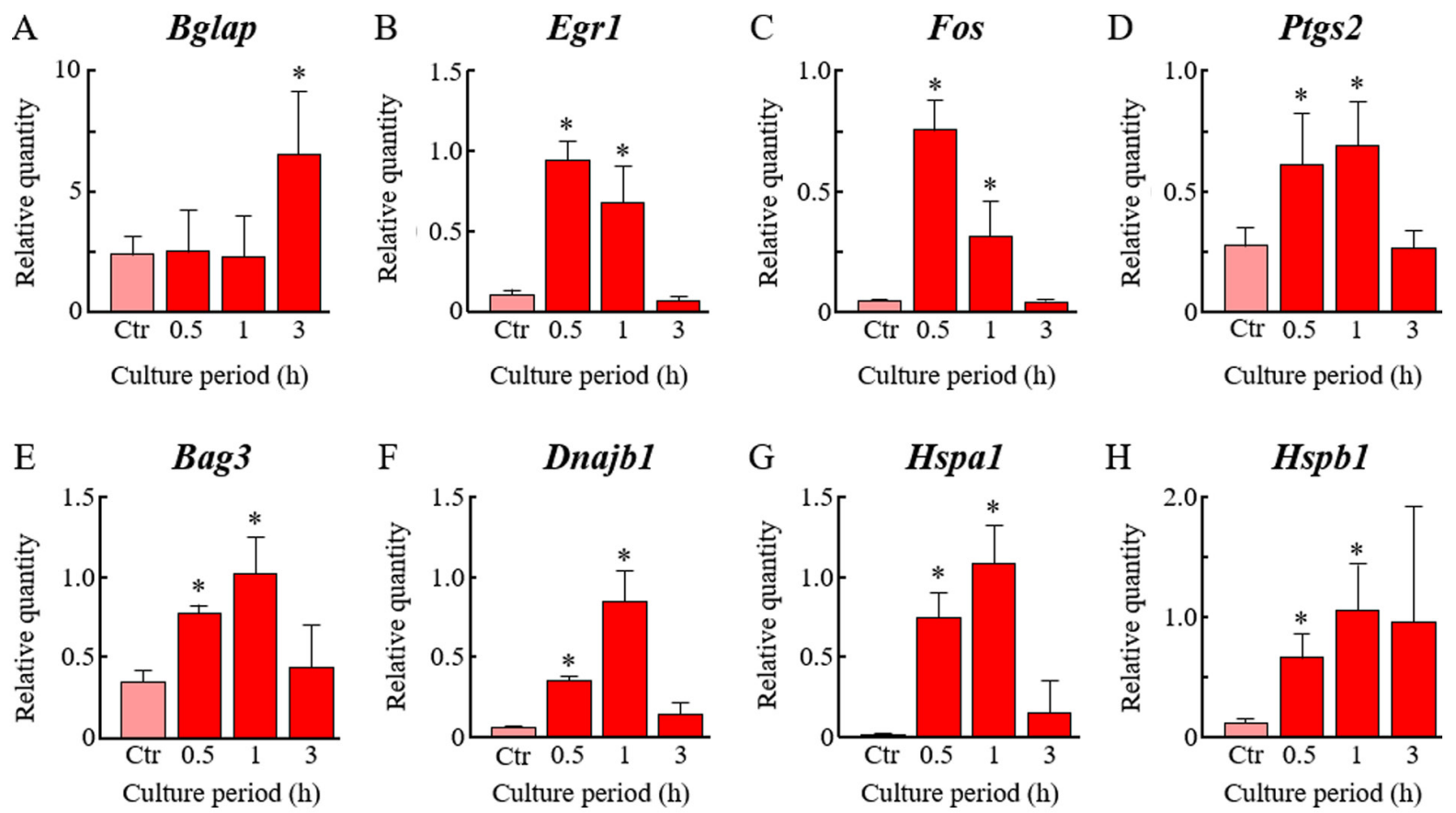

Figure 6. Verification of the upregulated genes determined via RT-qPCR. After treatment with low-intensity ultrasound at $25 \mathrm{~mW} / \mathrm{cm}^{2}$ for $20 \mathrm{~min}$, cells were cultured for $0.5,1$ or $3 \mathrm{~h}$ at $37^{\circ} \mathrm{C}$. RT-qPCR was performed with specific primers for (A) Bglap, (B) Egrl, (C) Fos, (D) Ptgs2, (E) Bag3, (F) Dnajb1, (G) Hspal and $(\mathrm{H})$ Hspb1. Levels were normalized to that of Actb. Non-treated cells were served as the Ctr. Data are presented as the mean $\pm \mathrm{SD}(\mathrm{n}=4)$. ${ }^{*} \mathrm{P}<0.05 \mathrm{vs}$. the Ctr group. RT-qPCR, reverse transcription-quantitative PCR; Ctr, control. Bglap, bone $\gamma$ carboxyglutamate protein; Egrl, early growth response 1; Fos, FBJ osteosarcoma oncogene; Ptgs2, prostaglandin-endoperoxide synthase 2; Bag3, BAG cochaperone 3; Dnajb1, DnaJ heat shock protein family (Hsp40) member B1; Hspal, heat shock protein 1a/b; Hspbl, heat shock protein 1.

A

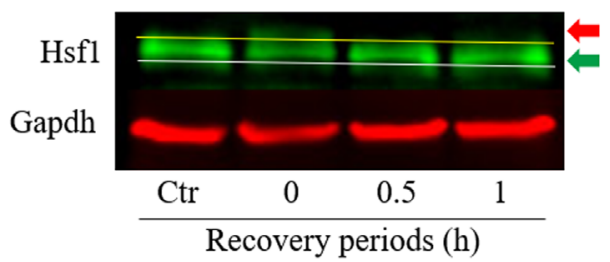

B

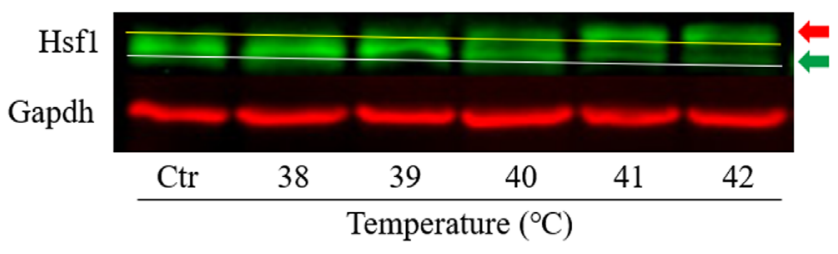

C

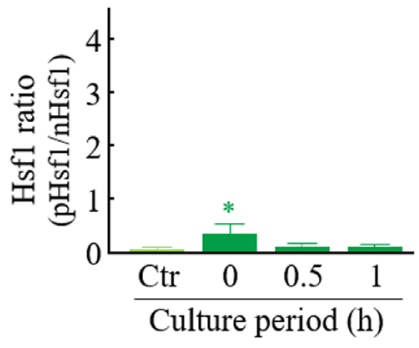

$\mathrm{D}$

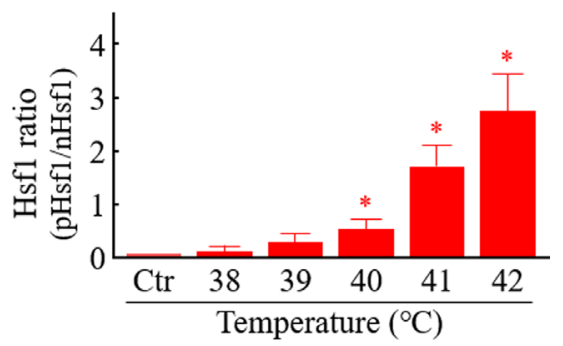

Figure 7. Effects of LIUS and heat on the activation of Hsf1 in ST2 cells. Cells were exposed to LIUS $\left(25 \mathrm{~mW} / \mathrm{cm}^{2}\right)$ or heat $\left(38,39,40,41\right.$ or $\left.42^{\circ} \mathrm{C}\right)$ for $20 \mathrm{~min}$, and cultured at $37^{\circ} \mathrm{C}$. (A and C) Cells were harvested $0,0.5$ or $1 \mathrm{~h}$ after LIUS exposure. (B and D) Cells were harvested immediately after heat exposure. Western blotting was carried out using specific primary antibodies against Hsf1 and Gapdh. Each Hsf1 band density was quantified, and the ratio (phosphorylated Hsf1 to non-phosphorylated Hsfl) was calculated. Gapdh served as a loading control. Green arrow indicates nHsfl. Red arrow indicates pHsf1. Data are presented as the mean $\pm \mathrm{SD}(\mathrm{n}=4-6)$. $\mathrm{P}<0.05$ vs. the Ctr group. LIUS, low-intensity ultrasound; Ctr, control; Hsf1, heat shock transcription factor 1; $\mathrm{p}$, phosphorylated; n, non-phosphorylated; Gapdh, glyceraldehyde 3-phosphate dehydrogenase. 
A

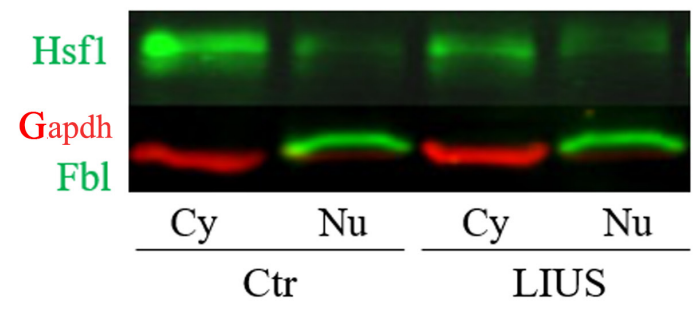

B
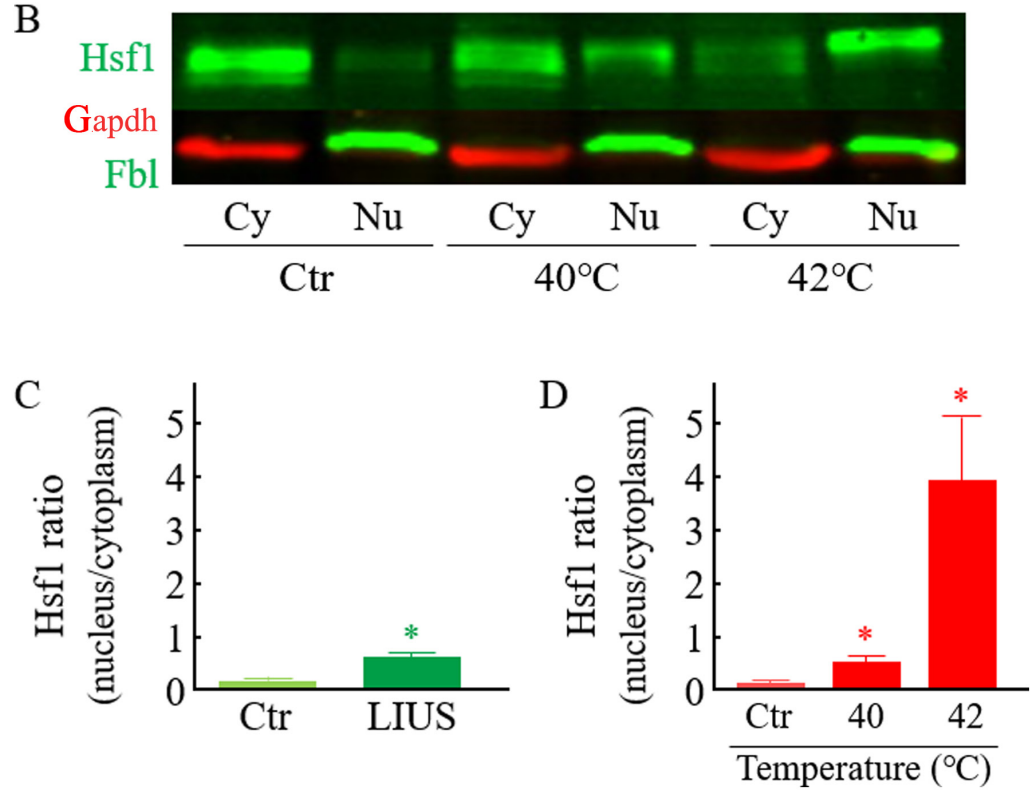

Figure 8. Effect of LIUS and heat on the intracellular localization of Hsf1 in ST2 cells. Cells were exposed to (A and C) LIUS (25 $\left.\mathrm{mW} / \mathrm{cm}^{2}\right)$ or (B and D) heat $\left(40\right.$ or $42^{\circ} \mathrm{C}$ ) for $20 \mathrm{~min}$. Immediately after stress treatment, cells were harvested. Either the cytoplasmic or nuclear fraction was separated. Western blotting was carried out using specific primary antibodies against Hsf1, Gapdh and Fbl. (C and D) Each band density of Hsf1 was quantified, and the ratio (nucleus to cytoplasm) was calculated. Gapdh and Fbl served as marker proteins for the cytoplasm and nucleus, respectively. Data are presented as the mean $\pm \mathrm{SD}(\mathrm{n}=4)$. "P $<0.05$ vs. the Ctr group. LIUS, low-intensity ultrasound; Hsf1, heat shock transcription factor 1; Fbl, fibrillarin; Ctr, control; Cy, cytoplasm; Nu, nucleus; Gapdh, glyceraldehyde 3-phosphate dehydrogenase.

gene networks in LIUS-treated mouse ST2 BMSCs. To our knowledge, this is the first report to identify changes in cellular gene expression as an early cellular response to LIUS.

In the present study, a number of genes (61 upregulated and 103 downregulated) that responded to LIUS at an early time point $(0.5$ to $3 \mathrm{~h})$ were found to be differentially expressed. Of these 164 genes, the expression levels of 3 genes (Bag3, Dnajbl and Hspal) and 4 genes [pentraxin related gene (Ptx3), Gjal, integrin beta 1 (Itgb1) and methionine aminopeptidase 2 (Metap2)] were reported to be affected $3 \mathrm{~h}$ after LIUS at $300 \mathrm{~mW} / \mathrm{cm}^{2}$ for $1 \mathrm{~min}$ in human leukemia Molt-4 (22) or lymphoma U937 cells (23), respectively. Except for these 7 genes, however, none of the genes identified here were reported in previous microarray investigations in which the gene expression patterns were monitored 3-24 h after LIUS (30-300 $\left.\mathrm{mW} / \mathrm{cm}^{2}\right)$ in several cell types $(18-23)$.

Particularly noteworthy in this study was the detection of gene network E, which contained 3 IEGs, i.e., Fos, Egrl, and Ptgs2, that were found to be associated mainly with the biological functions of bone physiology. IEGs respond to a wide variety of stresses, including LIUS (9-14). In our previous study, qRT-PCR analysis confirmed the up-regulation of the transient expression of these 3 IEGs in
LIUS-treated ST2 cells (13). Fos, Egr1, and Ptgs2 proteins are reported to have essential roles in bone formation (25,29-31). Our results showed that network E also included Bglap (32), Ednl (33) and Gjal (34), which are known to be involved in the differentiation of bone cells. It is thus intriguing that interactions have been reported between Fos on the one hand and Bglap (35), Ednl (36), Gjal (37) or Ptgs2 (38) on the other.

In this study, gene network $\mathrm{H}$ containing Hsf1-regulated genes - 7 HSP genes (39,40), Bag3 (39), Cryab (41) and $U b c$ (42) - was obtained from up-regulated genes and was associated principally with the biological functions of protein folding and apoptosis. The products translated from these genes are known to exert chaperonic and anti-apoptotic activity $(39,40)$. To our surprise, Ingenuity ${ }^{\circledR}$ pathway analysis indicated that the Hsf1 protein was activated at 0.5 to $3 \mathrm{~h}$ after LIUS stimulation (Fig. 4). We confirmed the transient activation of the Hsf1 protein by using Western blot analysis (Figs. 7 and 8). Under our experimental conditions, the medium temperature was increased from $35.3^{\circ} \mathrm{C}$ (control) to $38.1^{\circ} \mathrm{C}$ in LIUS-treated cells $\left(25 \mathrm{~mW} / \mathrm{cm}^{2}, 20 \mathrm{~min}\right)$. On the other hand, our previous study showed that heat treatment of the cells at $38^{\circ} \mathrm{C}$ for 20 min did not affect Fos expression (13). Zhang et al (16) previously reported that 
upregulation of the Hsp70 protein was observed in the human adipose-derived cells treated with LIUS at $30 \mathrm{~mW} / \mathrm{cm}^{2}$ for $30 \mathrm{~min}$, and the temperature in the medium increased from $37^{\circ} \mathrm{C}$ to $40^{\circ} \mathrm{C}$ during the LIUS exposure. Very weak but nonetheless significant heat-inducible heat shock element-binding activity of $\mathrm{Hsf} 1$ has been reported in cells incubated at $39^{\circ} \mathrm{C}$ for $20 \mathrm{~min}$ (43). Our previous paper also clearly indicated a transient activation of Hsf 1 at $0.5-1 \mathrm{~h}$ after mild hyperthermia treatment $\left(41^{\circ} \mathrm{C}\right.$, for $\left.30 \mathrm{~min}\right)$ in human lymphoma U937 cells (44). It is well known that Hsf1 can be activated by a wide variety of stressors, such as oxidative stress, heavy metals, toxins, and bacterial infections, in addition to heat (39). In addition, under nonthermal-LIUS conditions $\left(300 \mathrm{~mW} / \mathrm{cm}^{2}\right.$ for $1 \mathrm{~min}$; temperature rise in medium: $\left.0.3^{\circ} \mathrm{C}\right)$, the expression of HSP genes increased significantly in human leukemia Molt-4 cells (22). We considered that the induction of genes such as HSPs in gene network $\mathrm{H}$ may have been attributable, at least in part, to the activation of Hsf1 by the slight rise in temperature.

In the present study, LIUS decreased the expression levels of many genes. Previous findings demonstrated that heat activates the transcription of HSPs coincident with a bulk decrease in mRNA and protein syntheses, and this overall reprogramming of gene expression permits the selective synthesis of HSPs in mammalian cells (45). In the present study, we detected gene network $\mathrm{T}$, which contained many transcription factors in down-regulated genes. Functional analysis using the Ingenuity ${ }^{\circledR}$ Pathways Knowledge Base demonstrated that this network was associated with the biological functions of gene expression. For example, Etv5 (46), Fosl1 (47), Glis2 (48) and Srf (49) proteins increase the transcription of promoters by RNA polymerase II complex.

In conclusion, LIUS as shown to elicit gene expression even after short application in mouse ST2 BMSCs. The present results provide a basis for elucidation of the detailed molecular mechanisms underlying the cellular effects of LIUS. However, the biological roles of genes induced by LIUS in either cell or animal models remain a subject for further investigation. Therapeutic LIUS has been used to enhance bone healing caused by fracture in humans $(1,2)$. The effects and possible advantages of ultrasound have been a subject of increasing interest in other fields of medicine as well, including oncology, surgery, gene therapy and regenerative medicine (50-56). Therefore, genetic effects should also be considered to be a factor in these other fields.

\section{Acknowledgements}

Not applicable.

\section{Funding}

The present study was supported by JSPS KAKENHI (grant nos. 17K01353, 20K12619 and 20K06718).

\section{Availability of data and materials}

The datasets used and/or analyzed during the current study are available from the corresponding author on reasonable request.

\section{Authors' contributions}

YT and TM designed the experiments and wrote the paper. YT, TM, HH, NS, YF, TH, RN, JH and NH performed the experiments. YT, HH and TM analyzed the data. All authors read and approved the final manuscript.

\section{Ethics approval and consent to participate}

Not applicable.

\section{Patient consent for publication}

Not applicable.

\section{Competing interests}

The authors declare that they have no competing interests.

\section{References}

1. Padilla F, Puts R, Vico L and Raum K: Stimulation of bone repair with ultrasound: A review of the possible mechanic effects. Ultrasonics 54: 1125-1145, 2014.

2. Harrison A, Lin S, Pounder N and Mikuni-Takagaki Y: Mode \& mechanism of low intensity pulsed ultrasound (LIPUS) in fracture repair. Ultrasonics 70: 45-52, 2016.

3. Duarte LR: The stimulation of bone growth by ultrasound. Arch Orthop Trauma Surg 101: 153-159, 1983.

4. Azuma Y, Ito M, Harada Y, Takagi H, Ohta T and Jingushi S: Low-intensity pulsed ultrasound accelerates rat femoral fracture healing by acting on the various cellular reactions in the fracture callus. J Bone Miner Res 16: 671-680, 2001.

5. Hidaka K, Mikuni-Takagaki Y, Wada-Takahashi S, Saita M, Kawamata R, Sato T, Kawata A, Miyamoto C, Maehata Y, Watabe H, et al: Low intensity pulsed ultrasound prevents development of bisphosphonate related osteonecrosis of the jaw like pathophysiology in a rat model. Ultrasound Med Biol 45: 1721-1732, 2019.

6. Sun L, Sun S, Zhao X, Zhang J, Guo J, Tang L and Ta D: Inhibition of myostatin signal pathway may be involved in low-intensity pulsed ultrasound promoting bone healing. J Med Ultrason (2001) 46: 377-388, 2019.

7. Heckman JD, Ryaby JP, McCabe J, Frey JJ and Kilcoyne RF: Acceleration of tibial fracture-healing by non-invasive, low-intensity pulsed ultrasound. J Bone Joint Surg Am 76: 26-34, 1994.

8. Kristiansen TK, Ryaby JP, McCabe J, Frey JJ and Roe LR: Accelerated healing of distal radial fractures with the use of specific, low-intensity ultrasound. A multicenter, prospective, randomized, double-blind, placebo-controlled study. J Bone Joint Surg Am 79: 961-973, 1997.

9. Naruse K, Mikuni-Takagaki Y, Azuma Y, Ito M, Oota T, Kameyama $\mathrm{K}$ and Itoman $\mathrm{M}$ : Anabolic response of mouse bone-marrow-derived stromal cell clone ST2 cells to low-intensity pulsed ultrasound. Biochem Biophys Res Commun 268: 216-220, 2000.

10. Naruse K, Miyauchi A, Itoman M and Mikuni-Takagaki Y: Distinct anabolic response of osteoblast to low-intensity pulsed ultrasound. J Bone Miner Res 18: 360-369, 2003.

11. Sena K, Leven RM, Mazhar K, Sumner DR and Virdi AS: Early gene response to low-intensity pulsed ultrasound in rat osteoblastic cells. Ultrasound Med Biol 31: 703-708, 2005.

12. Louw TM, Budhiraja G, Viljoen HJ and Subramanian A: Mechanotransduction of ultrasound is frequency dependent below the cavitation threshold. Ultrasound Med Biol 39: 1303-1319, 2013.

13. Tabuchi Y, Hasegawa H, Suzuki N, Furusawa Y, Hirano T, Nagaoka R, Takeuchi SI, Shiiba M and Mochizuki T: Low-intensity pulsed ultrasound promotes the expression of immediate-early genes in mouse ST2 bone marrow stromal cells. J Med Ultrason (2001) 47: 193-201, 2020. 
14. Tang CH, Yang RS, Huang TH, Lu DY, Chuang WJ, Huang TF and Fu WM: Ultrasound stimulates cyclooxygenase- 2 expression and increases bone formation through integrin, focal adhesion kinase, phosphatidylinositol 3-kinase, and Akt pathway in osteoblasts. Mol Pharmacol 69: 2047-2057, 2006.

15. Costa V, Carina V, Fontana S, De Luca A, Monteleone F, Pagani S, Sartori M, Setti S, Faldini C, Alessandro R, et al: Osteogenic commitment and differentiation of human mesenchymal stem cells by low-intensity pulsed ultrasound stimulation. J Cell Physiol 233: 1558-1573, 2018.

16. Zhang Z, Ma Y, Guo S, He Y, Bai G and Zhang W: Low-intensity pulsed ultrasound stimulation facilitates in vitro osteogenic differentiation of human adipose-derived stem cells via up-regulation of heat shock protein (HSP)70, HSP90, and bone morphogenetic protein (BMP) signaling pathway. Biosci Rep 38: BSR20180087, 2018.

17. Su Z, Xu T, Wang Y, Guo X, Tu J, Zhang D, Kong X, Sheng Y and Sun W: Low intensity pulsed ultrasound promotes apoptosis and inhibits angiogenesis via p38 signaling mediated endoplasmic reticulum stress in human endothelial cells. Mol Med Rep 19: 4645-4654, 2019.

18. Leskinen JJ, Karjalainen HM, Olkku A, Hynynen K, Mahonen A and Lammi MJ: Genome-wide microarray analysis of MG-63 osteoblastic cells exposed to ultrasound. Biorheology 45: 345-354, 2008

19. Kobayashi Y, Sakai D, Iwashina T, Iwabuchi S and Mochida J: Low-intensity pulsed ultrasound stimulates cell proliferation, proteoglycan synthesis and expression of growth factor-related genes in human nucleus pulposus cell line. Eur Cell Mater 17: 15-22, 2009.

20. Lu H, Qin L, Lee K, Cheung W, Chan K and Leung K: Identification of genes responsive to low-intensity pulsed ultrasound stimulations. Biochem Biophys Res Commun 378: $569-573,2009$

21. Tabuchi Y, Sugahara Y, Ikegame M, Suzuki N, Kitamura K and Kondo T: Genes responsive to low-intensity pulsed ultrasound in MC3T3-E1 preosteoblast cells. Int J Mol Sci 14: 22721-22740, 2013

22. Tabuchi Y, Ando H, Takasaki I, Feril LB Jr, Zhao QL, Ogawa R, Kudo N, Tachibana K and Kondo T: Identification of genes responsive to low intensity pulsed ultrasound in a human leukemia cell line Molt-4. Cancer Lett 246: 149-156, 2007.

23. Tabuchi Y, Takasaki I, Zhao QL, Wada S, Hori T, Feril LB Jr, Tachibana K, Nomura $T$ and Kondo T: Genetic networks responsive to low-intensity pulsed ultrasound in human lymphoma U937 cells. Cancer Lett 270: 286-294, 2008

24. Bahrami S and Drabløs F: Gene regulation in the immediate-early response process. Adv Biol Regul 62: 37-49, 2016.

25. Wagner EF and Eferl R: Fos/AP-1 proteins in bone and the immune system. Immunol Rev 208: 126-140, 2005.

26. Tabuchi Y, Maekawa K, Torigoe M, Furusawa Y, Hirano T, Minagawa S, Yunoki T and Hayashi A: HIKESHI silencing can enhance mild hyperthermia sensitivity in human oral squamous cell carcinoma HSC-3 cells. Int J Mol Med 46 : 58-66, 2020.

27. Furusawa Y, Yamamoto T, Hattori A, Suzuki N, Hirayama J, Sekiguchi $\mathrm{T}$ and Tabuchi Y: De novo transcriptome analysis and gene expression profiling of fish scales isolated from Carassius auratus during space flight: Impact of melatonin on gene expression in response to space radiation. Mol Med Rep 22 2627-2636, 2020.

28. Sarge KD, Murphy SP and Morimoto RI: Activation of heat shock gene transcription by heat shock factor 1 involves oligomerization, acquisition of DNA-binding activity, and nuclear localization and can occur in the absence of stress. Mol Cell Biol 13: 1392-1407, 1993

29. Cenci S, Weitzmann MN, Gentile MA, Aisa MC and Pacifici R: M-CSF neutralization and egr-1 deficiency prevent ovariectomy-induced bone loss. J Clin Invest 105: 1279-1287, 2000 .

30. Demiralp B, Chen HL, Koh AJ, Keller ET and McCauley LK: Anabolic actions of parathyroid hormone during bone growth are dependent on c-fos. Endocrinology 143: 4038-4047, 2002

31. Choudhary S, Halbout P, Alander C, Raisz L and Pilbeam C: Strontium ranelate promotes osteoblastic differentiation and mineralization of murine bone marrow stromal cells: Involvement of prostaglandins. J Bone Miner Res 22: 1002-1010, 2007.
32. Paredes R, Arriagada G, Cruzat F, Villagra A, Olate J, Zaidi K, van Wijnen A, Lian JB, Stein GS, Stein JL, et al: Bone-specific transcription factor Runx2 interacts with the 1alpha,25-dihydroxyvitamin D3 receptor to up-regulate rat osteocalcin gene expression in osteoblastic cells. Mol Cell Biol 24: 8847-8861, 2004.

33. Salama M, Andrukhova O, Jaksch P, Taghavi S, Kelpetko W, Dekan G and Aharinejad S: Endothelin-1 governs proliferation and migration of bronchoalveolar lavage-derived lung mesenchymal stem cells in bronchiolitis obliterans syndrome. Transplantation 92: 155-162, 2011.

34. Hashida Y, Nakahama K, Shimizu K, Akiyama M, Harada K and Morita I: Communication-dependent mineralization of osteoblasts via gap junctions. Bone 61: 19-26, 2014.

35. Owen TA, Bortell R, Yocum SA, Smock SL, Zhang M, Abate C, Shalhoub V, Aronin N, Wright KL and van Wijnen AJ: Coordinate occupancy of AP-1 sites in the vitamin D-responsive and CCAAT box elements by Fos-Jun in the osteocalcin gene: Model for phenotype suppression of transcription. Proc Nat Acad Sci USA 87: 9990-9994, 1990.

36. Rodríguez-Pascual F, Redondo-Horcajo $\mathrm{M}$ and Lamas $\mathrm{S}$ : Functional cooperation between Smad proteins and activator protein-1 regulates transforming growth factor-beta-mediated induction of endothelin-1 expression. Circ Res 92: 1288-1295, 2003.

37. Johnston IM, Spence HJ, Winnie JN, McGarry L, Vass JK, Meagher L, Stapleton G and Ozanne BW: Regulation of a multigenic invasion programme by the transcription factor, AP-1: Re-expression of a down-regulated gene, TSC-36, inhibits invasion. Oncogene 19: 5348-5358, 2000.

38. Subbaramaiah K and Dannenberg AJ: Cyclooxygenase-2 transcription is regulated by human papillomavirus 16 E6 and E7 oncoproteins: Evidence of a corepressor/coactivator exchange. Cancer Res 67: 3976-3985, 2007.

39. Barna J, Csermely P and Vellai T: Roles of heat shock factor 1 beyond the heat shock response. Cell Mol Life Sci 75: 2897-2916, 2018.

40. Richter K, Haslbeck M and Buchner J: The heat shock response: Life on the verge of death. Mol Cell 40: 253-266, 2010.

41. Hayashida N, Fujimoto M, Tan K, Prakasam R, Shinkawa T, Li L, Ichikawa H, Takii R and Nakai A: Heat shock factor 1 ameliorates proteotoxicity in cooperation with the transcription factor NFAT. EMBO J 29: 3459-3469, 2010.

42. Le Masson F, Razak Z, Kaigo M, Audouard C, Charry C, Cooke H, Westwood JT and Christians ES: Identification of heat shock factor 1 molecular and cellular targets during embryonic and adult female meiosis. Mol Cell Biol 31: 3410-3423, 2011.

43. Tanabe M, Nakai A, Kawazoe Y and Nagata K: Different thresholds in the responses of two heat shock transcription factors, HSF1 and HSF3. J Biol Chem 272: 15389-15395, 1997.

44. Tabuchi Y, Takasaki I, Wada S, Zhao QL, Hori T, Nomura T, Ohtsuka K and Kondo T: Genes and genetic networks responsive to mild hyperthermia in human lymphoma U937 cells. Int J Hyperthermia 24: 613-622, 2008

45. Spriggs KA, Bushell M and Willis AE: Translational regulation of gene expression during conditions of cell stress. Mol Cell 40: 228-237, 2010.

46. Degerny C, Monte D, Beaudoin C, Jaffray E, Portois L, Hay RT, de Launoit Y and Baert JL: SUMO modification of the Ets-related transcription factor ERM inhibits its transcriptional activity. J Biol Chem 280: 24330-24338, 2005.

47. Finzer P, Soto U, Delius H, Patzelt A, Coy JF, Poustka A, zur Hausen $\mathrm{H}$ and Rösl F: Differential transcriptional regulation of the monocyte-chemoattractant protein-1 (MCP-1) gene in tumorigenic and non-tumorigenic HPV 18 positive cells: The role of the chromatin structure and AP-1 composition. Oncogene 19: 3235-3244, 2000

48. Vasanth S, ZeRuth G, Kang HS and Jetten AM: Identification of nuclear localization, DNA binding, and transactivating mechanisms of Kruppel-like zinc finger protein Gli-similar 2 (Glis2). J Biol Chem 286: 4749-4759, 2011.

49. Cordes KR, Sheehy NT, White MP, Berry EC, Morton SU, Muth AN, Lee TH, Miano JM, Ivey KN and Srivastava D: miR-145 and miR-143 regulate smooth muscle cell fate and plasticity. Nature 460: 705-710, 2009.

50. Sirsi SR and Borden MA: Advances in ultrasound mediated gene therapy using microbubble contrast agents. Theranostics 2 : 1208-1222, 2012

51. Maloney E and Hwang JH: Emerging HIFU applications in cancer therapy. Int J Hyperthermia 31: 302-309, 2015. 
52. Boissenot T, Bordat A,FattalE and Tsapis N: Ultrasound-triggered drug delivery for cancer treatment using drug delivery systems: From theoretical considerations to practical applications J Control Release 241: 144-163, 2016.

53. Lafond M, Yoshizawa S and Umemura SI: Sonodynamic therapy: Advances and challenges in clinical translation. J Ultrasound Med 38: 567-580, 2019.

54. Mikolajczyk A, Khosrawipour T, Kulas J, Migdal P, Arafkas M, Nicpon $J$ and Khosrawipour V: The structural effect of high intensity ultrasound on peritoneal tissue: A potential vehicle for targeting peritoneal metastases. BMC Cancer 20: 481, 2020.
55. Xia C, Zeng $\mathrm{H}$ and Zheng Y: Low-intensity ultrasound enhances the antitumor effects of doxorubicin on hepatocellular carcinoma cells through the ROS-miR-21-PTEN axis. Mol Med Rep 21: 989-998, 2020.

56. de Lucas B, Pérez LM, Bernal A and Gálvez BG: Ultrasound therapy: Experiences and perspectives for regenerative medicine. Genes (Basel) 11: E1086, 2020.

c) (i) (3) This work is licensed under a Creative Commons EY NG NO Attribution-NonCommercial-NoDerivatives 4.0 International (CC BY-NC-ND 4.0) License. 